\title{
4 The War Expands and the People Mobilize
}

\section{Farmers and Fishermen}

As Oita Prefecture was still dependent on fishing, farming, and small enterprises during the war, most of the children at that time came from families of modest means. Young Kou Takeda's family lived as farmers in Saiki, as did Tafumi Yoshimura's family in Usa and Toyoki Goto's in Oita City. Yoshio Ninomiya helped his father in the local fish market, and Tadashi Ono's father owned a two-wheeled cart which he used to deliver rice to households after picking it up from a train or ship.

Sadayoshi Yutani, born in 1939, did not see his father until a year after the end of the war.

My father was an employee for the Japan National Rail Company. By the time I was born, he'd been sent off to work in Thailand, constructing its railway system. The company paid him and he sent money home to my grandparents and mother. We had a picture of him in the house that I bowed to every day, but I had no memory of him. He was just a common worker, not an engineer, and worked in different places in Southeast Asia. Have you seen the movie, Bridge over the River Kwai? You can see in the movie where he worked. After the war, he was imprisoned in Singapore. When he came home, I was already a primary school student.

Former Japanese prime minister Tomiichi Murayama was the son of a fisherman in Oita, and for the first few years of war his life changed little. Education for those like him, for example, was limited both before and during the war. "We did not have a high school in my district so we went to elementary school and then to higher elementary schools for two years. Those who wanted to continue their education would take placement tests for higher-level schools like the middle and high schools these days. But my family was poor, and I only completed the minimum required education, which was eight years. I started working but, at the same time, attended a night school, so that I could go to university later." During the war years Murayama and his six brothers all joined the military, three fighting in China. Murayama joined the army when he was 20 years old, the required 
age for enlisting during the war, though he never left Japan. Remarkably, all the brothers survived the war. He recalls:

Joining the military was not voluntary. It was a mandate. Very simple: when we turned 20, we joined up. There was a health check, and all those passing the health check were automatically enlisted. It was a direct command. No notification letter of any kind, you just went when you turned 20. ${ }^{1}$ There were people who had ailments or for some reason or other didn't go at the time. But they'd get drafted later if needed. This was part of the Japanese constitution that you would be conscripted for three years when you turned 20. If there was no war, you would be done in three years. But because we were at war, the country required you to stay longer. If you had done your military duties before the war started and you were recalled, that was when you'd receive a letter to reenlist with the military.

\section{Guarding the Emperor}

Isematsu Matsumoto, from a farming family in the village of Ooga, had similar experiences as a young man, but his fate took a different turn. Young Isematsu spent the war guarding the life of the emperor and his family in Tokyo. He explains:

In the 1930s, elementary schools offered a regular education, no military training. We studied subjects such as Japanese, ethics, math, and science. Of course, everyone knew of the war in China. At the time, Japan had done nothing wrong. China had attacked Japanese soldiers stationed in China, though it was called an "incident" and not a war. ${ }^{2}$ China even appealed to the League of Nations to support them, even though Japan had a right to be in China.

I remember once Mamoru Shigemitsu came to my school to speak to students about the war. That was a special event, because Mamoru

1 This statement conflicts that of many others who remembered receiving a letter around the time of their $20^{\text {th }}$ birthday telling them to report.

2 This was the Manchurian Incident of September, 1931, widely reported in Japan as aggression by China against Japan, despite the fact it took place within China against an occupying force. When referring to this event Chinese use the term “事变” while Japanese use “事件”. Both terms are translated into English as "incident" when, in fact, the Japanese term denotes a far smaller scale event. 
Shigemitsu was a well-known person from our area, who later became foreign minister of Japan. In April 1932, he'd been injured by a bomb in an assassination attempt in Shanghai. It must have been about six months after his injury. When he came to the school, we immediately stopped our work and greeted him by bowing. When I saw that he limped and had to walk with a cane, I thought, "Wow, men coming back from the war are so honorable."

Our military training started in middle school. At that time, middle school lasted three years. After that, some students went to vocational school. In rare cases, usually only one from my school, a few would go on to college preparation programs.

Because of the conscription system, my middle school set up a military preparation program, and I joined the program for five years. I studied academic subjects in the morning and trained in military drills in the afternoon. We learned how to fight in a battle, how to attack the enemy, and how to avoid being shot. We learned to use our environment to protect ourselves while approaching the enemy. We also learned how to carry out attacks at close range. We only had wooden guns for those exercises. Since I had to help support my family by working in the fields I went only two or three times a week. But I was considered a good candidate for the military at the time.

Students would usually graduate, and then enlist in the military when we turned 20. But some would join up before graduating from the program. I was one of those that joined the military in January, without graduating. Conscription had priority over completing one's education. I took an army placement test, made the highest marks from our school and entered the military before graduation. The placement test was administered by officers from the headquarters in Oita City. We underwent health checks and IQ tests. A month later, those of us who did well would find out about our assignments. The village mayors wrote letters of recommendation for us, but we had no choice in our assignment. The year was 1941.

I was assigned to the Konoeihei $2{ }^{\text {nd }}$ Unit, the Royal Guard. My job was to guard the emperor. There were only four of us chosen from Oita Prefecture, so this was a very high honor. I was excited and happy to get this appointment, but also awed by the responsibility, and I worried I wouldn't measure up. The four of us from Oita soon headed for Tokyo. Before being allowed inside the palace grounds, we spent a month learning how to stand at attention properly, behave properly, and march properly. We were not to write down any orders and instructions from our superior officers, because it could breach security. We had to memorize everything. Part of 
our training was in combat since we never knew when we'd be called to the front. So we were trained as soldiers as well as guards. It was not until September that I finally entered the palace to begin my duty of guarding the emperor. I spent the next four years at the palace, until the end of the war. I was lucky that I never had to fight at the front.

Isematsu Matsumoto's firsthand experience as an imperial guard fundamentally challenged his basic beliefs, especially in the divinity of the emperor, as he became one of the few people in Japan to actually see the emperor and interact with the family.

Up until the time I entered the palace, I believed that the emperor was a god and I was very curious what a god looked like. On Emperor Hirohito's birthday, April 29, 1942, a big festival was held inside the palace. The emperor came riding on a horse and carried a shield. That was the first time I saw him as a man. Later, when I was on duty standing guard at a building behind the palace, the emperor would often pass by to go study biology, which was his hobby. We were always notified of the exact time of his passing, so we had to stand with extra vigilance. We'd take our helmets off and bow extra low. It was during these times, seeing the emperor coming and going, that I fully realized he was a man, just like all of us, not a god. I was also deeply impressed by the beauty of the empress. The fact that she was actually a woman, not a goddess at all, struck me profoundly! Nevertheless, she was, indeed, a very beautiful human being.

The young Prince Akihito, who later became the emperor following the death of his father, was about ten at that time. In the winter, the royal family would go down to the southern palace because it was warmer. I often saw the boy running around playing tag down the beach. When I had a bit of time between my shifts, I'd go down to the beach to play hide-and-seek with him. We had always been taught that the emperor and his family were gods and goddesses, who never erred and always protected us. Now I knew that it was not so. I was not disappointed, though, to find out that he was not a god. Instead, I was actually pleased. ${ }^{3}$ 


\section{Empty Urns}

Community participation in local Buddhist ceremonies became commonplace in the early years of the war as more and more men died fighting overseas. Seiichi Kogo was a primary school student in Oita City in the mid-1930s, during Japan's military surge in China. When not in school, he spent his time working in the family sweetshop alongside his mother and grandmother, which had been in operation since the early days of Meiji, around the mid-186os. He recalls the feelings of a young boy being introduced to a country at war.

I had a close friend whose father went to China. He joined the army rather early in the war, joining the $47^{\text {th }}$ Oita Regiment with many of his friends and neighbors. He had received the "Red Letter" from the government instructing him to report to the army. The soldiers went off one by one, walking to the Oita train station for their departure. We didn't always go to the station but would see them off from our town. There wasn't any special ceremony when they left. I was still in elementary school, when his family was notified that he died soon after arriving in China. I attended a Buddhist ceremony when his remains were returned to the family. There was a military base near Ochiji Middle School. A tent was set up, and we lit incense for him and others who had been killed. They were all from the $47^{\text {th }}$ Oita Regiment. Each soldier's ashes was placed into its own urn and wrapped in white cloth. The urns were lined up next to each other on the podium. Many people attended the ceremony. We stood in silence and bowed. There was a monk who lit incense and sounded the gongs. For us kids it was a funny ceremony, and we were trying not to laugh. As I think about it now, I know that was very rude, but, at the time, we found the whole thing weird.

The war in China quickly evolved into one vast military effort that covered most of East Asia and the Pacific. Deaths multiplied as the fighting intensified and spread. One might enter the war fighting in China, but end the war on a ship, a beach, in a jungle, or a cave somewhere in the Pacific, killed by American bullets or flame throwers. Japanese soldiers expected to die, and were told, outright, they should die rather than lose the fight or be taken prisoner by the enemy. This was spelled out in Hideki Tojo's 1940 "Instructions for the Battlefield," written as a guide to "ideal soldierly conduct." It concluded, "Do not suffer the shame of being captured alive."4 
Soon, orderly return of dead combatants ceased and families grieved with no remains to intern. During her $100^{\text {th }}$ year, in 2012, Masako Ono sat down to reflect on her family's story during those years. "I attended a girls' school in my early years and remember playing in the mountains around Ajimu. My family owned a small shop, selling liquor and snacks. Our life was quite simple and peaceful. I got married and moved to Beppu during the war with China. I don't remember wartime life being difficult during the early years. It all changed, though, when my brother was inducted into the army. Then it became difficult. He died three or four years later on a ship that was attacked by Americans."

Masako's brother was a young officer in command of $5^{\circ}$ men. Masako's son Yosuo Ono continues the story:

All the men under his command were from Oita, and they trained right here prior to leaving for the war. My uncle went to war right at the beginning of combat in the Philippines. Japan had been winning when he arrived, but he was killed soon afterward. Before he left for the Philippines, he'd prepared himself to die. Like other soldiers, he had clipped his finger nails and a piece of his hair and put them in an envelope. This was for the family to remember him by. Just before going into battle, his personal belongings were stored away in case he was killed. The family never got his remains back. He was probably ripped to shreds. But because this was still early in the war and Japan still had some order, they did get some of his personal belongings and the envelope he had prepared. Not many men from Beppu had died up to that point. Our family even got paid handsomely from the government because of his sacrifice and service.

An army delegation came to the family to return my uncle's belongings. They brought a small box and said it held the bones of my uncle. I was young and curious. When no one was around, I opened it to see the bones, but there was only a piece of paper with his name on it. This is all we could take to the temple. There was a ceremony at the local temple where the residents came together and placed a stone marker in his memory and honor. Japanese tradition is that you visit the grave once a year. We still go to the temple even now, and the monks are there for us.

\section{Pure Spirit of the Saipan Children}

As the war intensified, young men not yet 20 years old, the legal age of conscription in Japan, began to volunteer for special service. One volunteer 
was Jiro Nakano of Beppu. As a high school student, he yearned to join the war and in October 1942, at the age of 16 , he passed the screening test to train as a telegraph operator in the Naval Youth Communication branch. Jiro left high school early and in April 1943 graduated from the Armory Engineer Training Center in Kokura, a city about 70 kilometers north of his home in Beppu. In May, he entered the Naval Communication School in Bofu, graduating in February 1944. He immediately left Japan with the $753^{\text {rd }}$ Naval Aviation Force bound for Indonesia. Due to his youth, Jiro was not forced to go overseas, but he requested to join the front lines as a volunteer. Knowing his mother feared losing her son, he did not discuss this with his family, nor did he inform them of the decision until just before he left. While his job was not to carry a weapon, but to maintain, transport, and operate the telegraph machine, he could not escape the horrors of war and remembers them vividly almost seven decades later.

I was dispatched to the $753^{\text {rd }}$ Naval Aviation Force at Kaohsiung Naval Base in Taiwan. When we left Kaohsiung on route to Indonesia, my ship was struck by a torpedo, so we had to anchor for three days in Cam Ranh Bay in Vietnam. After completing repairs, we set off for Singapore where we docked, boarded the Noshiro Maru and headed to Surabaya in Indonesia. After arriving in Surabaya, we changed to another ship. The Senko Maru was to take us to the island of Borneo. However, at 4:0o a.m. on the morning of March 24 the Senko Maru hit a mine as she entered Balikpapan Bay. At the moment of the explosion, I was on duty, corresponding by telegraph in the communication room. At the first blast, I was thrown to the floor, almost knocked unconscious. I fell hard on my tailbone, and I have suffered from that impact ever since. I crawled out to the deck of the ship, but water had rushed on board, and I was washed overboard. I saw many Indonesians, who had been sleeping on the top deck, slipping into the water at the same time. There were about 300 Indonesian workers and 200 Japanese soldiers on the ship. As most of the soldiers were sleeping in makeshift rooms on tatami mats below the deck, many of them drowned. I floated in the sea for most of that day, holding on to a pole that had been washed out of the ship's cargo. My skin became spongy, and I came very close to total exhaustion by the time I was picked up that evening. I was sent to a navy hospital in Indonesia, and then transferred to a hospital in Saipan by a navy escort ship..$^{5}$

5 Personal memoirs of Jiro Nakano (中野次郎) shared with the authors, written with his granddaughter when he was 79 years old, Beppu, Oita Prefecture, Japan. 
While recovering in Saipan, Jiro was visited by schoolchildren from the island. Saipan had been controlled by Japan since the end of World War I and thousands of Japanese lived on the island, with their families serving as government bureaucrats, educators, businessmen, sugarcane farmers and, of course, military personnel. In the spring of 1944 it was a quiet place except for Japanese military activity. For the wounded it served as peaceful respite from the hell of war, and for Jiro one memory from that time sticks out as one of his clearest of the war. It is a memory filled with mixed emotions, as he relates, "The schoolchildren from the Third National School on Saipan Island visited us in the hospital and taught me how to make origami cranes. I never forgot their visits." Leaving Saipan, Jiro boarded a ship bound for Tinian, "an island just like floating in the sea." He and his comrades did not know their final destination, but for a short while he had time to reflect on his life and his future. The near-death experience on the Senko Maru had awakened him to the realities of this war.

I went out of my barracks quietly, walking along a pathway in the middle of a cane field. I wanted to walk alone. Long leaves of sugarcane were making sounds on both sides of the path. I knew I was going to the front tomorrow, and death was standing right in front of me. I recalled my mother's face and regretted that I had volunteered without her consent and I couldn't be home to take care of her. Had I stayed home, her life would have been easier, and mine, too. I wiped my tears and said in my heart, "I'm sorry, mother. Please look after yourself and forgive me. I am going to die before you." A strong wind then began blowing from the sea, and I returned slowly back to the barracks. ${ }^{6}$

Soon Jiro moved with his unit to their Indonesian base. It was there that he heard what happened to those children after he left Saipan. "After we moved to Indonesia, the Battle of Saipan started. Because I was on the telegraph machine, I was the first to hear the news that after the American Army landed on the island, the children who taught me to make origami cranes killed themselves to protect the honor of their families, their emperor, and their country. They died hero's deaths."

Reflecting on these deaths seven decades after the war, the memories of the children remain fresh as he shares his tender feelings for the kindness shown him by these young people. At the same time, he still holds 
unqualified pride for what he calls the "honorable deaths and pure spirit of those children." He concludes simply, "I was deeply moved."

While Jiro may still respect the "honorable deaths" of children, such sentiment is unfathomable to others. Certainly this is true for the Americans witnessed those deaths first hand. It is difficult to reconcile, even after so many years, this divide between Japanese honor leading to the deaths of children and an American soldier's anguish at watching innocent deaths. Those who watched in horror as men, women, and children died by their own hands, or the hands of their parents, can never forget the scene. Lieutenant Colonel Justice M. Chambers of the $4^{\text {th }}$ Marine Division in Saipan remembers:

During the day as we moved along the cliffs and caves, we uncovered civilians all the time. The Jap soldiers would not surrender, and would not permit the civilians to surrender. I saw with my own eyes women, some carrying children, come out of the caves and start toward our lines. They'd be shot down by their own people. I watched any number of women carrying children come down to the cliffs that dropped into the ocean. They were very steep, very precipitous. The women would come down and throw the children into the ocean and jump in and commit suicide. I watched one group at a distance of perhaps 100 yards, about eight or ten civilian men, women and children get into a little huddle and blow themselves up.... It was a sad and terrible thing, and yet I presume quite consistent with the Japanese rules of Bushido. ${ }^{9}$

Lieutenant Frederic A. Stott of the same division witnessed similar self-destruction.

Interpreters were summoned, and they pleaded by amplifier for the civilians to come forward in surrender. No movement followed. The people drew closer together into a compact mass. It was still predominantly civilians, but several in uniform could be distinguished circling about in the throng and using the civilians for protection. As they huddled closer, sounds of a weird singing chant carried up to us. Suddenly a waving flag of the Rising Sun was unfurled. Movement grew more agitated; men

8 Ibid.

9 Quoted in Captain John C. Chapin, Breaching the Marianas: The Battle for Saipan, Washington, D.C.: Marine Corps Historical Center, 1994), pp. 35-36, http://ibiblio.org/hyperwar/USMC/ USMC-C-Saipan/index.html. 
started leaping into the sea, and the chanting gave way to startled cries and with them the popping sound of detonating grenades. It was the handful of soldiers, determined to prevent the surrender or escape of their kinfolk, who tossed the grenades into the milling throng of men, women, and children, and then dived into the sea from which escape was impossible. The exploding grenades cut the mob into patches of dead, dying, and wounded, and for the first time we actually saw water that ran with human blood. ${ }^{10}$

This eighteen-year-old boy from Beppu would see much more of war, and survive to tell his stories. We will revisit him later as Japan stands on its last legs and Jiro does his best to get home to his mother. 